Article

\title{
Determinants of Financial Sustainability for Farm Credit Applications-A Delphi Study
}

\author{
Johannes I. F. Henning ${ }^{\dagger, *}$ and Henry Jordaan ${ }^{\dagger}$ \\ Received: 9 November 2015; Accepted: 6 January 2016; Published: 14 January 2016 \\ Academic Editor: Manfred Max Bergman \\ Department Agricultural Economics, University of the Free State, 205 Nelson Mandela ave, Bloemfontein 9301, \\ South Africa; jordaanh@ufs.ac.za \\ * Correspondence: henningjif@ufs.ac.za; Tel./Fax: +27-(051)-401-9713 \\ + These authors contributed equally to this work.
}

\begin{abstract}
Farmers use credit from commercial credit providers to finance production activities. Commercial credit providers have to predict the financial sustainability of the enterprise to ensure that the borrower will have the ability to repay the loan. A Delphi study was conducted to explore what factors are used as indicators of loan-repayment ability of farmers. The objective was not only to identify factors that are currently considered, but also to identify other personal attributes that may improve the accuracy in predicting the repayment ability of potential borrowers. The Delphi was applied to a panel consisting of nine credit analysts and credit managers from a commercial credit provider in South Africa. The results indicate that the current and past financial performance, account standing, collateral, and credit record of the farm are very important in the assessment of applications in terms of financial performance. Experience and the success factors compared to competitors were found to be important, while age and education/qualification are regarded as less important in predicting repayment ability. The results also show that, although not currently objectively included in credit evaluations, credit analysis regards leadership and human relations; commitment and confidence; internal locus of control; self-efficacy; calculated risk taking; need for achievement; and opportunity seeking as important indicators of the ability of potential borrows to repay their loans. Thus, credit analysts and managers also regard management abilities and entrepreneurial characteristics of potential borrowers to be good indicators of repayment ability. Results from this research provide new indicator factors that can be used to extend existing credit evaluation instruments in order to more accurately predict repayment ability.
\end{abstract}

Keywords: financial sustainability; credit repayment ability; delphi technique; personal attributes

\section{Introduction}

Improved and sustainable productivity in the agricultural sector plays a very important part in economic development [1]. Concerns regarding the sustainability of agricultural systems include the development of new technologies and practices that do no harm to environmental goods and services, which are accessible and effective to farmers, and which lead to enhanced food productivity [2]. Although great progress has been made in the productivity of agriculture over the past half-century, one question remains: Can this progress continue into the future?

The continuation of production worldwide depends on the combination of natural resources and human beings with the ability to take advantage of those resources [3]. Hou [4] argues that the ability to raise financial capital is one of the most important factors for the survival and growth of a business. Credit is part of financial capital, and can help farmers to gain from financial resources beyond their own abilities and therefore take advantage of possible profitable business opportunities [5]. The ability 
to raise financial capital is an essential factor in farming production. Without access to credit, most farmers would be unable to reap the maximum returns from the natural resources available to them. However, despite the importance of credit, it is not accessible to everybody. A better understanding of the factors that are considered in credit applications can assist farmers in the preparation of their applications, or even provide guidance in advance when the farmer is considering applying for credit, in terms of ensuring that certain key attributes of the farm are in place.

The research explored factors that affect farmers' access to credit, focusing on factors such as age, gender, education, experience, farm size, household size, income, group membership, and source of credit [6]; distance between lender and borrower, perception of loan repayment, perception of lending proceedings, and value of assets [7]; marital status, and lack of guarantor [8]. Akudugu et al. [9] and Dzadze [10] mention that for rural banks, the crop that is grown, farm size and savings are the main determinants of credit supply. Several studies (i.e., [6-8,11]) found credit repayment ability, or the effects of factors that influence repayment ability, to be indicators of future repayment ability. Researchers often do not include all the factors that are considered in actual credit applications for determining repayment ability, because information is not obtained from commercial or agricultural banks. As such, researchers seeking to determine repayment ability could possibly omit some important factors and/or include less important factors in their work, which could lead to a financial institution incorrectly awarding or rejecting a loan to a prospective borrower, with the resulting cost implications. The aim of this research is therefore to explore the current credit assessment process to understand the factors and characteristics that are used to assess credit applications, and to identify other factors and characteristics that could improve the degree of accuracy with which repayment ability is predicted. Such information can be used to improve the accuracy of the instruments used to award credit to applicants.

The paper presents an alternative view of the indicators used in the agricultural credit process by considering the process from the credit providers' perspective and not from the borrowers. Credit research tends to view the process from the borrowers perspective. Characteristics and factors that are considered by the credit providers are identified in the Delphi procedure, but the research is expanded to identify additional factors, which are currently not considered or are problematic in the process. In previous research, information describing the individual would mostly consist of factors related to human capital such as age, education, and experience. The factors identified by the research are a consideration of the entrepreneurial and management capabilities and behavior of an individual such as leadership and human relations, creativity and innovation, internal locus of control, self-confidence (self-efficacy), persistence, planning, passion, opportunity seeking, conflict management, risk management, need for achievement, positivity, tenacity, commitment, and confidence. These factors do have an influence on the performance of the farming business and can also differ between individuals. This makes it necessary to consider these entrepreneurial and management capabilities of the individual when determining repayment ability. The results and findings of the research can be used to extend the current repayment indicators by including these factors and characteristics by means of an objective measurement, which could improve the accuracy of the current credit instruments.

The following section of the paper discusses the method and data used in the research. Once the short discussion of methods and data used is completed the application of the Delphi procedure is discussed in terms of the results for each of the rounds needed to achieve consensus between the respondents. A discussion of the factors identified is also presented in the section. The last section of the paper discusses the conclusions made from the research and how the findings can contribute to the current credit process and instruments used. 


\section{Method and Data Used}

\subsection{Method}

The Delphi technique was used to determine the level of consensus among individuals involved in determining the repayment ability of loan applicants. Delbecq et al. [12] indicate that the Delphi technique can explore or expose the underlying assumptions or information leading to differences in judgment, or can seek out information that may generate consensus among individuals in a respondent group. The Delphi technique [13] is widely used for purposes of achieving convergence on real world opinions from experts within specific topic areas [14], through a series of questionnaires used to collect data from a selected panel in view of achieving consensus [13,15-19]. The Delphi technique does not make use of a representative random sample of a target population, but rather a panel of experts is used; with an expert being an individual who is considered to be an expert in the relevant research area [20]. The Delphi process starts with an initial questionnaire that acts as an idea-generating strategy to uncover the issues related to the specific topic or to identify several broad aspects that are related to the specific topic in question. The relevant question for the research is to identify the factors considered and new factors that need to be considered in credit applications. Responses from the initial questionnaire must provide as many relevant issues as possible, as these issues are the foundation for the continuation of the process [20], where the identified aspects are used for further refinement that could lead to consensus on the important factors that need to be considered. The complete process can thus extend into several iterations, where the previous iteration forms the foundation for the next which is important in the process that assists in reaching consensus between the responders on what are the factors used to determine the repayment ability of applicants.

These multiple iterations develop into a consensus on the different opinions concerning the topic in question [14]. Every feedback process provides an opportunity for each of the participants to reassess his or her initial opinion in relation to the responses of the other responders [14], who remain anonymous during the entire process [21-23]. The feedback process consists of a summary of the previous iteration's answers and forms part of a new questionnaire. The number of rounds depends on, amongst other things, the time available and whether it is only a single broad question to be answered, or several questions [20]. In some instances where the Delphi technique has been used, two or three rounds have proven sufficient to reach consensus [24-26].

\section{Level of Consensus}

The level of consensus reached after each round determines the need for another round in the research process. Different methods exist to determine the level of consensus amongst different opinions, as well as the level of agreement among respondents, the coefficient of variations, the interquartile range, and standard deviation. Loughlin and Moore [27] found that consensus could be achieved with 51\% agreement amongst respondents, while Seagle and Iverson [28] found $60 \%$ for a specific score on a five-point Likert scale. Putman, Spiegel. and Bruininks [29] found consensus to be reached with $80 \%$ agreement falling within two measures of a five-point Likert scale.

The coefficient of variation is a method used to measure the spreading of opinions. Coefficient of variation has been used in several Delphi studies to measure consensus, as it allows for the direct comparison of succeeding rounds. An indication of consensus is that the coefficient of variation decreases from one round to the next [30,31]. A coefficient of variation of less than 0.5 indicates a reasonable internal agreement [32]. The level of consensus as determined by the coefficient of variation is shown Table 1. 
Table 1. Coefficient of variation cut-off points and decision rules.

\begin{tabular}{cc}
\hline Coefficient of Variation & Decision Rule \\
\hline $0 \leqslant \mathrm{~V} \leqslant 0.5$ & Good degree of consensus, no additional round \\
$0.5<\mathrm{V} \leqslant 0.8$ & Less than satisfactory consensus, possible need for another round \\
$0.8 \leqslant \mathrm{~V}$ & Poor degree of consensus, need for additional round \\
\hline & Source: English and Keran [33].
\end{tabular}

The interquartile range (IQR) is a measure of dispersion for the median, consisting of the middle $50 \%$ of observations [34]. IQR is a method that is frequently used in Delphi studies, as it is an objective and rigorous means of determining consensus among respondents [30]. The rule of thumb is that for a five-point Likert scale, an IQR of one or less is a suitable indication of consensus.

Standard deviation (SD) is a measurement used to assess the variation in a population. In a normal distribution, $68 \%$ of scores will fall within one SD above and below the mean [35]. For purposes of this study, the level of consensus indicated by Grobbelaar [35] was used as a guideline on which to base decisions of consensus in terms of SD, as shown in Table 2.

Table 2. Decision criteria used in determining level of consensus achieved according to standard deviation.

\begin{tabular}{cc}
\hline Standard Deviation & Level of Consensus Achieved \\
\hline $0 \leqslant x \leqslant 1$ & High level \\
$1.01 \leqslant x \leqslant 1.49$ & Reasonable/fair level \\
$1.5 \leqslant x \leqslant 2$ & Low level \\
$2 \leqslant x$ & No consensus \\
\hline & Source: Grobbelaar [35].
\end{tabular}

\subsection{Data Used}

The Delphi was conducted between November 2014 and April 2015, with the participants being nine credit analysts and managers from a commercial bank in South Africa. The respondents, which were identified by a representative of the bank, were all involved in the decision-making process relating to the granting of credit in the agricultural sector, including applications by farmers. The questionnaires were sent to the aforementioned bank representative via electronic mail and subsequently distributed to the respondents. The resulting feedback was sent to either the representative or the main researcher.

Information was also obtained by reviewing actual credit application documents, which provided a more detailed description of the factors mentioned in the Delphi and also served to identify additional factors not mentioned in the answers from round one of the Delphi study. The additional characteristics mentioned by respondents were compared to the literature and included in round two.

\section{Results and Discussion}

\subsection{Round One}

The result of the first round or the exploratory round has been reported by [11]. In order to ensure that the questionnaire did not elicit biased responses from the experts [17], two open-ended questions were used. The first question was aimed at identifying the factors and characteristics in an application used to judge the applicant's repayment ability [11]:

Question 1: What are the personal characteristics and aspects of a farmer that are considered important in assisting with credit applications? Which capabilities of a farmer are considered when writing the credit report that forms part of the credit application process? 
The second question was aimed at identifying factors or characteristics not currently considered in credit applications, as well as any other areas of the credit application process that could be improved [11]:

Question 2: In your opinion, are there any additional characteristics or factors that influence repayment ability, which are not being considered?

It is important to note that while some of the characteristics are included in the application, they are not based on objective measurements, but rather on the banker's personal experience and knowledge of the applicant.

\subsubsection{Factors Currently Being Considered (Question 1)}

Prominent factors that are considered in credit applications where identified when mentioned by at least three of the respondents. These factors were: management capability (100\%); sustainability of the enterprise (86\%); past and current financial performance (86\%); account standings and credit record (86\%); experience (57\%); reputation (57\%); collateral (43\%); client success factor compared to competitors (43\%); education/qualifications ( $43 \%)$; willingness to repay (43\%); and farm ownership (29\%) [11]. Less important factors that are also considered in the applications include: succession planning, bounce-back ability, labor force, strategic position of the business, business model, type of farming enterprise, external market and market projections, and business environment [11].

Apart from the mentioned factors, the following information of the farmers was also found to be important in the review process: age and experience of the operator, importance of the debt ratio and profitability of the business, market projections and information, and the influence of the client's financial position compared to the risk taken by the lender. Characteristics such as age and experience are inherent aspects and beyond the control of the farmer. Farmers are expected to learn the necessary skills early in their farming life and to become more proficient as time goes on [36]. As expected, experience comes with age, with age being a non-psychological factor that influences decisions in terms of exploiting opportunities [37]. The age of the farmer has an effect on his or her decision-making process, which could be one of the reasons why this factor is included in the application. Decisions are made with different goals in mind and at different levels of a farmer's respective lifecycle, and these decisions influence the ultimate farm performance. However, factors such as experience are not something that can be taught, learned, or adjusted in a short period of time, thus implying that younger, less experienced farmers are at a disadvantage. The aspects that are related to human capital such as age, education, and experience do have an influence on the management capabilities of farmers. Older, more experienced farmers have gone through several learning experiences already which younger less experienced farmers still have to learn, and this can also mean that these younger farmers could possibly make more mistakes in their decisions that can influence the performance of the farming business. The respondents emphasised the management capabilities of the farmer as being important. These are also related to the financial performance of the farm, because decisions influence the daily activities and sustainable financial performance of the farming business. Importantly, some of the characteristics reported in the application are not based on any objective measurements; instead, the banker bases his or her judgement on personal experience and knowledge of the applicant [11].

Thus, similar to what was found in the literature [38-40], the credit evaluation process in South Africa is shown to relate to the five Cs (capacity, capital, collateral, conditions, character) of credit. These results therefore confirm the importance of the five Cs of credit within the agricultural sector in South Africa.

\subsubsection{Additional Factors Indicated by Respondents (Question 2)}

Most factors that are not measured or which are problematic are related to financial aspects [11]. The dynamic nature of the agricultural sector is also reflected in the responses in terms of sensitivity testing of income (which are related to price and yields), expenditures, and how the farmer would 
be able to absorb deviations in the market [11]. Unpredictability in the agricultural industry along with several external factors influence the daily activities (e.g., weather) and turnaround strategies or adjusting strategies are also considered to be highly important [11].

Individual characteristics and management capabilities of the applicant that were reported as being important and considered or need to be considered included: reputation, integrity, abilities, honesty, reliability, as well as innovation, risk behavior, leadership, entrepreneurship, open mindedness, perseverance, and business awareness [11]. The factor of "abilities" can be reported in several categories, namely financial, technical, marketing, general business, and human relations abilities [11]. Besides the performance of the farm, several personal abilities of the farmer are also considered, but indications are that these aspects are only considered on a subjective basis. This was also illustrated by the variation in responses by the different respondents where some indicated the aspects as currently measured and other in the additional factors section, which shows that these attributes still provide difficulty in the process.

The farmer has to manage the farming business which involves the daily activities as required including financial, production, and human resources among others. This highlights the importance of the management capabilities of the farmer and was also mentioned by Respondent 3 [11]: "Management Capability: The farmer's reputation, ability and willingness to repay the debt are assessed. This includes his/her integrity, honesty and reliability. His background is assessed his qualifications or experience as well as his track record as a farmer. This aspect is considered the most imperative, but yet the most difficult to assess." Another respondent, Respondent 5, also highlighted several aspects that are not currently measured but that do have an influence on the repayment ability. These factors include honesty, accepting responsibility for actions, adaptability, and having a positive attitude [11]. These abilities are also considered in the review process of the application, but as mentioned are reported on subjective measures and reporting.

Most of the factors that were mentioned and reported by Henning and Jordaan [11] can be related to the factors and skills that are associated with psychological capital and entrepreneurial skills and competencies. According to Luthans et al. [41] positive psychological capital of an individual relates to: "(1) having confidence (self-efficacy) to take on and put in the necessary effort to succeed at challenging tasks; (2) making a positive attribution (optimism) about succeeding now and in the future; (3) persevering towards goals and, when necessary, redirecting paths to achieve goals in order to succeed (hope); and (4) when beset by problems and adversity, sustaining and bouncing back and even beyond in order to attain success (resilience)".

Skills that are associated with entrepreneurship can be of great assistance to farmers. The dynamic nature of agriculture can also result in great opportunities in the sector, and the entrepreneurial farmer would be able to see the opportunity and take advantage. Other factors such as self belief or self-efficacy also assist a person through difficult times, as that person will have belief in his or her own abilities to perform tasks [42]. Not only is the ability to be entrepreneurial very important but also the management of the business throughout is of great importance. This fact is also emphasised by Respondent 3: "Management capabilities of the farmer is most imperative, but difficult to assess." From these short explanations it is very clear that these management and entrepreneurial capabilities of farmers are very important in the future existence of the farming business. An objective means of measuring these characteristics, skills, and attributes is lacking in the current credit assessment process. As these factors are only considered subjectively, it can contribute to inconsistent reporting between different applications; which leads the subjective measuring to be considered as a shortcoming in the current credit application assessment process [11].

Additional characteristics identified by respondents, and as compared to the literature, are illustrated in Table 3. Lambing and Kuehl [42] and Baron and Shane [43] also emphasise the skills or associated factors listed in Table 3 as important for a successful business.

Many of these factors are skills that are and can be associated with entrepreneurial and managerial competence. Research has shown that entrepreneurial and managerial competence has an influence on the competitiveness and financial performance of small- and medium-enterprise businesses. In the entrepreneurship context, competencies are related to the birth, survival, and/or 
growth of a venture [44-46]. The skills of an entrepreneur are a contributing factor to performance and growth [44,47]. Furthermore, Chandler and Jansen [48] mention that the development of entrepreneurial skills contributes to the profitability and growth of a firm. There are several factors that have been associated as influential in the performance of firms, including the entrepreneur's demographic, psychological, and behavioral characteristics and the individual's skills and technical know-how [49]. The skills that are illustrated in Table 3 are essential to run and manage a successful business. The factors that are considered in determining the repayment ability of agricultural credit applications have now been identified, and their importance when considering applications is now addressed.

Table 3. Characteristics and associated factors identified by respondents in round one and from the literature included in round two.

\begin{tabular}{|c|c|}
\hline Additional Characteristics Identified from Question 2 and the Literature & Associated Factor \\
\hline Ability to build a team and to give responsibility and credit when due & Leadership and human relations \\
\hline $\begin{array}{l}\text { Applying new ideas, for example adjusting or refining an existing product; } \\
\text { identifying new opportunities with a solution }\end{array}$ & Creativity and innovation \\
\hline Belief that others or chance control destiny & External locus of control \\
\hline Belief that one is in control of one's own destiny & Internal locus of control \\
\hline Belief in own abilities & Self-confidence \\
\hline Belief in own ability to perform tasks and to be successful & Self-efficacy \\
\hline Belief in the business despite setbacks & Persistence \\
\hline Dealing with problems as they occur rather than anticipating beforehand & Planning \\
\hline Enjoying what one is doing in all activities & Passion \\
\hline $\begin{array}{l}\text { Good personal interactions, trusting in people, and giving recognition } \\
\text { when deserved }\end{array}$ & Leadership \\
\hline $\begin{array}{l}\text { Ability to adjust to an ever-changing environment and to use change to } \\
\text { one's advantage }\end{array}$ & Opportunity seeking \\
\hline Ability to handle conflict between various stakeholders of the business & Managing conflict \\
\hline Ability to take on calculated risk opportunities & Risk management \\
\hline In control of situations with good delegation skills & Locus of control \\
\hline $\begin{array}{l}\text { Internally driven by strong desires to compete and excel against self-imposed } \\
\text { standards in order to pursue and attain goals }\end{array}$ & Need for achievement \\
\hline Observing more opportunities than threats & Positivity \\
\hline Observing more strengths than weaknesses & Positive attitude \\
\hline Overcoming hurdles and obstacles & Tenacity \\
\hline Planning ahead for possible problems that may be encountered & Planning \\
\hline Pursuing business with a "go get it" attitude & Passion \\
\hline Willingness to commit personal resources to the business & Commitment and confidence \\
\hline
\end{tabular}

\subsection{Round Two}

A second questionnaire was developed based on the first-round responses. The second round tested the degree to which the respondents agreed on the findings of the first round, while reviewing the additional information and factors identified from the literature. The option to add additional information was also available to respondents if they felt information had been omitted. The questionnaire consisted of statements to which the respondents again answered according to a five-point Likert scale, in terms of how important the statements were in their credit process. A score of five indicated that the factor was very important, while a score of one indicated it was not important. An important purpose of the second round was to determine the degree of consensus among the respondents' answers. 
The results of the second round are shown in Table 4. There were high levels of consensus (SD $\leqslant 1$ ) among the financial factors, including account standing, credit record, past and current performance, sustainability of the enterprise, and willingness to repay. There were still, however, factors that did not have a high level of consensus. Of the factors that are currently considered in credit applications, only 2 of 15 had a reasonable level of consensus $(1.01 \leqslant \mathrm{SD} \leqslant 1.49)$. All the other factors had a high level of consensus.

Table 4. Summary of results for the Delphi second round, illustrating the average, standard deviation, mode, median, and consensus level for factors as mentioned by respondents.

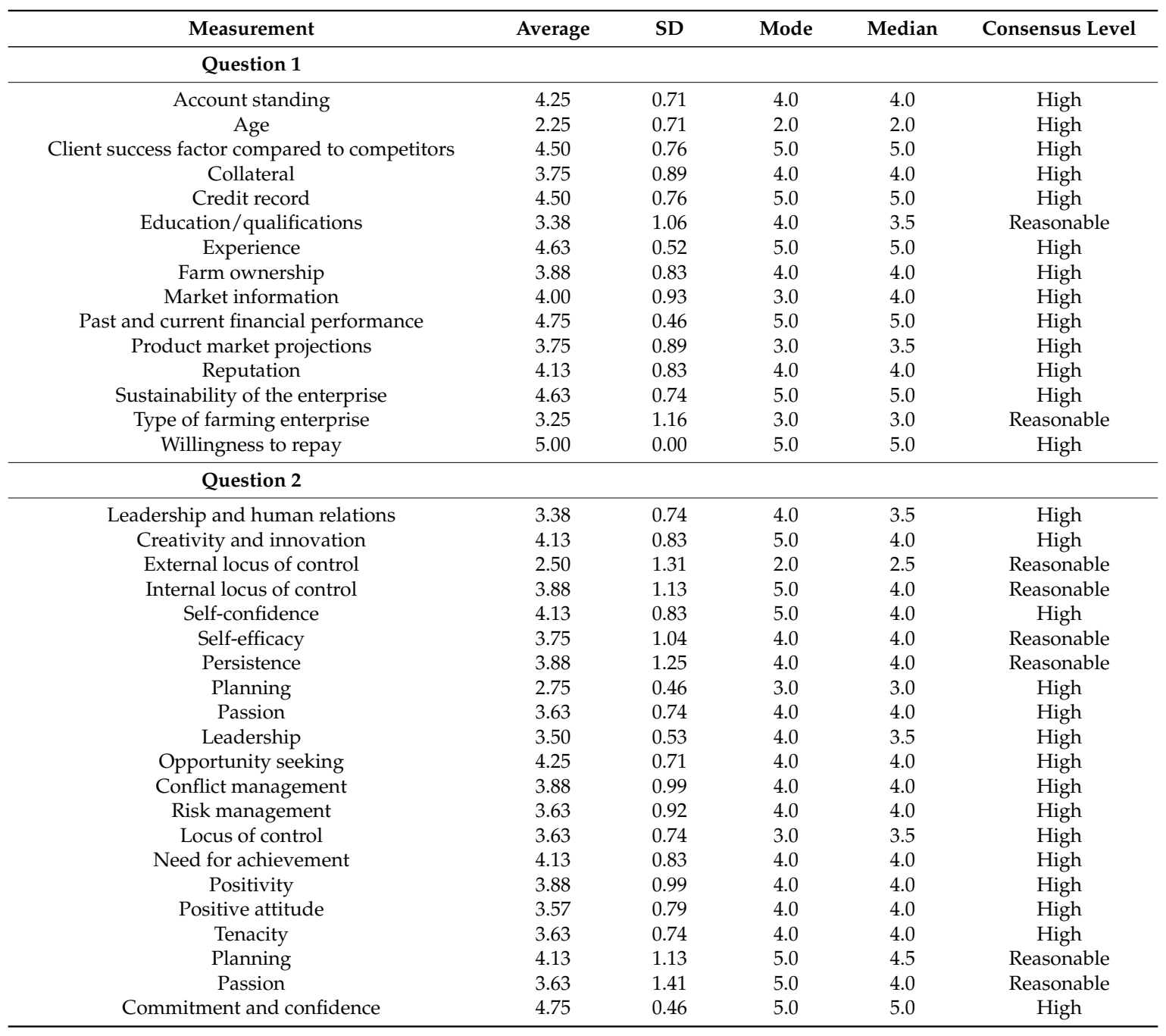

The mode and medians of the factors with a high level of consensus are equal, suggesting that there is little or no room for improvement. There are, however, also factors that have a high level of consensus with modes and medians that are not equal. The difference between the mode and the median suggests that there is still room to improve the level of consensus among the respondents.

Interestingly, more factors that were not currently measured fell within the reasonable consensus level $(1.01 \leqslant \mathrm{SD} \leqslant 1.49)$. Two of the statements related to the opposite ends of locus of control (external and internal), namely belief that others or chance control destiny, and belief to be in control of one's own destiny, both of which fell within the reasonable consensus level (SD of 1.31 and 1.13, respectively). The second factor is related to self-efficacy (belief in one's own ability to perform tasks and to be successful) with an SD of 1.04. Belief in the business despite setbacks (persistence) is an important factor (average 3.88), with a reasonable consensus level (SD 1.25). 
The consensus levels reported in Table 4 suggest scope for improvement regarding the factors that can be used to predict farmers' repayment ability and to assess credit applications. To obtain a higher level of consensus, a third round was used. The respondents in the second round provided no additional factors, and therefore the third round included the same factors as the second round.

\subsection{Round Three (Final Round)}

With the third round, the respondents received feedback from the second round and had the opportunity to determine whether they still agreed or would like to adjust their original answers. The feedback was given by means of the average scores and the mode for each of the factors and statements of questions one and two. The midpoint of the responses was categorized using the median score. It is normally expected that in each succeeding round, the range of responses from the panelists will decrease and the median will be closer to the score of the final answer [35]. Results for the third round are shown in Table 5.

All factors deemed reasonable in the second round, with the exception of internal locus of control, were changed to a high consensus level in the third round. Thus, the factors of question one all achieved a high level of consensus in the third round, indicating that the respondents agreed with the factors determining the repayment ability of farmers.

Table 5 also shows that the reasonable consensus levels of external locus of control, self-efficacy, persistence, planning, and passion, changed to high consensus levels. This means that only one factor still remained at a reasonable level of consensus. An advantage is that as external locus of control is the opposite of internal locus of control, and with high consensus levels, the results are not difficult to interpret. The results in Table 5 therefore provide evidence that acceptable levels of consensus were reached after the completion of the third round.

Respondents' consensus indicate the factors that are important and do not provide difficulty in determining farmers' repayment ability in credit applications. The factor that was identified as the most important, with an average score of 4.44 and equal mode and median of 5 , was commitment and confidence. This is a clear indication, from the original statement, that a farmer must be willing to commit and have confidence in himself or herself and the opportune venture to commit his or her own resources and time, for the bank to be willing to provide finance.

Anticipation was also very important, as the ability of the farmer to plan ahead was indicated with an average score of 4 . Further confirmation was that inability to plan ahead and only deal with problems as they occur rather than anticipating beforehand was found to be not important. It can therefore be concluded that the bank would be more willing to provide finance to a farmer that anticipates problems beforehand and plans accordingly than to farmers who only deal with problems as they arise. By only considering problems as they arise places the farmers at a disadvantage compared to when problems were anticipated and possible solutions are already in place or could be implemented in a short time frame.

Self-confidence, self-efficacy, and internal locus of control were found to be important, with average scores of 3.78, 3.67, and 3.33, respectively. The modes and medians for these factors were all equal with a score of 4 . Farmers must, according to these scores, believe in their abilities; believe that they have the ability to perform tasks in the business; and also believe that their behavior will have an influence on the destiny or ultimate performance of the business. These factors ensure that the farmer will continue with the business despite setbacks (average score of 3.78; equal mode and median of 4) and take advantage of opportunities that have been identified. Opportunity seeking, with an average score of 4.11, is also an indication of the ability to adjust to an ever-changing environment and to use the change to their advantage. The identification of opportunity can also be related to the positive attitude of the farmer. A more positive farmer will identify more opportunities than threats and will also concentrate on his or her business strengths instead of weaknesses. The positivity factor had an average score of 3.56 and an equal mode and median of 4 . Applying new ideas, adjusting or refining an existing product or identifying new market opportunities are related to creativity and 
innovation, which is also considered when determining the repayment ability of farmers. Creativity and innovation achieved an average score of 3.78 and equal mode and median of 4.

Table 5. Summary of results for the Delphi third round, illustrating the average, standard deviation, mode, median, and consensus level for factors as mentioned by respondents.

\begin{tabular}{|c|c|c|c|c|c|}
\hline Measurement & Average & SD & Mode & Median & Consensus Level \\
\hline \multicolumn{6}{|l|}{ Question 1} \\
\hline Account standing & 4.44 & 0.53 & 4.00 & 4.00 & High \\
\hline Age & 2.22 & 0.44 & 2.00 & 2.00 & High \\
\hline Client success factor compared to competitors & 4.00 & 0.71 & 4.00 & 4.00 & High \\
\hline Collateral & 3.44 & 0.53 & 3.00 & 3.00 & High \\
\hline Credit record & 4.67 & 0.71 & 5.00 & 5.00 & High \\
\hline Education/qualifications & 3.44 & 0.73 & 4.00 & 4.00 & High \\
\hline Experience & 4.56 & 0.73 & 5.00 & 5.00 & High \\
\hline Farm ownership & 3.67 & 0.87 & 4.00 & 4.00 & High \\
\hline Market information & 3.89 & 0.60 & 4.00 & 4.00 & High \\
\hline Past and current financial performance & 5.00 & 0.00 & 5.00 & 5.00 & High \\
\hline Product market projections & 4.00 & 0.71 & 4.00 & 4.00 & High \\
\hline Reputation & 3.67 & 1.00 & 4.00 & 4.00 & High \\
\hline Sustainability of the enterprise & 5.00 & 0.00 & 5.00 & 5.00 & High \\
\hline Type of farming enterprise & 3.22 & 0.97 & 3.00 & 3.00 & High \\
\hline Willingness to repay & 5.00 & 0.00 & 5.00 & 5.00 & High \\
\hline \multicolumn{6}{|l|}{ Question 2} \\
\hline Leadership and human relations & 3.22 & 0.83 & 4.00 & 3.00 & High \\
\hline Creativity and innovation & 3.78 & 0.83 & 4.00 & 4.00 & High \\
\hline External locus of control & 2.56 & 0.73 & 3.00 & 3.00 & High \\
\hline Internal locus of control & 3.33 & 1.12 & 3.00 & 3.00 & Reasonable \\
\hline Self-confidence & 3.78 & 0.67 & 4.00 & 4.00 & High \\
\hline Self-efficacy & 3.67 & 0.50 & 4.00 & 4.00 & High \\
\hline Persistence & 3.78 & 0.67 & 4.00 & 4.00 & High \\
\hline Planning & 2.89 & 0.78 & 3.00 & 3.00 & High \\
\hline Passion & 3.56 & 0.53 & 4.00 & 4.00 & High \\
\hline Leadership & 3.44 & 0.53 & 3.00 & 3.00 & High \\
\hline Opportunity seeking & 4.11 & 0.60 & 4.00 & 4.00 & High \\
\hline Conflict management & 3.67 & 0.50 & 4.00 & 4.00 & High \\
\hline Risk management & 3.78 & 0.67 & 4.00 & 4.00 & High \\
\hline Locus of control & 3.44 & 0.53 & 3.00 & 3.00 & High \\
\hline Need for achievement & 3.67 & 0.50 & 4.00 & 4.00 & High \\
\hline Positivity & 3.56 & 0.53 & 4.00 & 4.00 & High \\
\hline Positive attitude & 3.56 & 0.53 & 4.00 & 4.00 & High \\
\hline Tenacity & 3.67 & 0.50 & 4.00 & 4.00 & High \\
\hline Planning & 4.00 & 1.00 & 3.00 & 4.00 & High \\
\hline Passion & 3.78 & 0.67 & 4.00 & 4.00 & High \\
\hline Commitment and confidence & 4.44 & 0.73 & 5.00 & 5.00 & High \\
\hline
\end{tabular}

Taking advantage of opportunity involves strategic thinking, especially the consideration of risk that is associated with the opportunity. Results from the third round indicated that the ability of the farmer to take calculated risk (average score of 3.78) is an important factor in determining the repayment ability in credit applications. Even though risk taking is associated with higher returns, not all risky ventures will lead to greater returns. As one of the objectives of banks is to minimise their risk, the investment in high-risk ventures can have a negative influence on credit applications.

A business requires the owner and/or manager to take a leading role to ensure that the required processes are in place. Whether the farming business is a family business that only involves family members in the daily activities or even when permanent or casual labor is used, the relation between the farmer and the other members are very important. Leadership and human relations were found to be an important aspect, but as can be expected, conflict also exists in teamwork. Teamwork involves having trust in the abilities of others, the ability to divide work confidently and give the necessary recognition. The ability to handle conflict is therefore also very important. These aspects are related to networking. It is not always necessary to build a team, as vital information can also be obtained by communicating with others. The management of conflict had an average score of 3.67 , and equal mode 
and median of 4. Leadership and human relations had an average score of 3.22, but the difference in the mode and the median indicate differences of opinions from the respondents.

The results indicated that the entrepreneurial and management abilities of a farmer are very important and need to be considered by means of an objective and consistent method in credit applications. Man, Lau, and Chan [50] identified six areas of entrepreneurial competencies from literature for small and medium enterprises, and also for businesses managed by an individual. The six competencies include opportunity, relationship, conceptual, organizing, strategy, and commitment. Each one of the competencies has underlying skills or competencies which can be related to the behavior of a farmer in terms of behavior in leadership and human relations, creativity and innovation, internal locus of control, self-confidence (self-efficacy), persistence, planning, passion, leadership, opportunity seeking, conflict management, risk management, need for achievement, positivity, tenacity, commitment, and confidence. Opportunity competence relates to recognizing and developing market opportunities [50]. Networking and human relations can be related to the person-to-person or person-to-group based interactions, included in the relationship competence of Man et al. [50]. According to Man et al. [50] conceptual competence is related to the conceptual abilities of the individual. These abilities are reflected in behavior such as decision-making skills, absorbing and understanding complex situations, problem analysis, vision, and judgment. The organization and leading of internal and external human, physical, financial, and other resources are all skills or competencies that are associated with the organizing competence [50]. Strategic competencies are related to the setting, evaluation, and implementation of strategies in the business. Underlying competencies are related to learning from past behavior and results orientation. There needs to be a drive that ensures the anticipated results of the venture, which is also an important factor for determining the repayment ability. The last competency factor, i.e., commitment, is related to the drive of the individual to move forward. Factors such as self-confidence, self-efficacy, and persistence can be associated with the factors that ensure the continuation of venture. All the factors identified by the respondents in Question two can be associated with a certain competence as proposed by Man et al. [50]. This is an indication that the framework proposed by Man et al. [50] can be used to provide valuable and additional information on these aspects that are related to the entrepreneurial and management abilities of farmers in determining the repayment ability in credit scoring.

The respondents were also asked to indicate whether the approach used to measure each of the factors was objective or subjective. Three of the respondents did not answer the question, but there was an agreement between the respondents who answered. The respondents agreed that the additional factors related to question two, which was associated with manager and entrepreneurial skills, were all based on subjective measurements. While the factors such as financial performance, age, experience, education, ownership, collateral, market and product situation, and projections and the type of farming operations were mostly based on objective measures, it was also further indicated by several respondents that the final decision on repayment ability is based on human judgement, which is a subjective conclusion.

Not only is human judgement very subjective in decision making, research found several shortcomings that are associated with personal judgement procedures. These shortcomings include aspects such as unreliability, results are not replicable, and possible problems with the handling of large quantities [51]. Apart from decision-making problems, the judgement methods suffer from high training costs, frequent incorrect and inconsistent decision making by different experts when considering the same application [52]. Human judgement does provide challenges when used in the credit process, especially considering consistency between applications or even between credit analysis and managers. Challenges arise whether human judgement is included in the final decision-making or when used to analyze aspects within the process, consistency cannot be guaranteed. 


\section{Conclusions}

The main objective of the research was to explore the current agricultural credit assessment process, to understand the factors and characteristics used to assess credit applications, and to identify any other factors and characteristics that could improve the degree of accuracy with which repayment ability is predicted. Although several researchers have previously investigated the credit process and the factors influencing access to credit, the data used in their analyses was mostly gathered through questionnaires or sourced from farmers, and since the information did not originate from a financial institution, it could easily omit several important aspects in determining the repayment ability of applicants. This situation resulted in a gap in the knowledge necessary to ensure a proper understanding of the characteristics and variables that are actually considered by existing credit providers and financial organizations today.

A Delphi study was conducted to determine the characteristics and variables considered important by a financial organization in determining the repayment ability of farmers in South Africa. In total, 15 different factors were identified as being important when evaluating a credit application. Factors that were found to be important in the credit process included: account standing, age, client success factor compared to competitors, collateral, credit record, education/qualifications, experience, farm ownership, market information, past and current financial performance, product market projections, reputation, sustainability of the enterprise, type of farming enterprise, willingness to repay. As expected, the most important factors included the financial performance, sustainability, and security of the applicant. Age, experience, and education, which are often cited in the literature as factors that influence access to credit, are also considered in the application process, but are considered to be less important than the other mentioned factors.

The respondents identified a number of additional personal characteristics and abilities of the farmer that should be considered in the credit application process, including certain managerial and entrepreneurial characteristics such as the ability to manage different aspects of the farm business (financial, technical, production, marketing, natural resources, and human resources). The research has identified several entrepreneurial and management capabilities that are considered to be important in credit evaluation instruments. These factors include: leadership and human relations, creativity and innovation, internal locus of control, self-confidence (self-efficacy), persistence, planning, passion, leadership, opportunity seeking, conflict management, risk management, need for achievement, positivity, tenacity, commitment, and confidence. The aspects of the individual related to the characteristics used to describe the entrepreneurial competencies explained in literature and by Man [50] consisting of opportunity, relationship, conceptual, organizing, strategy, and commitment competencies. The entrepreneurial abilities of the farmer indicate a degree of promise in the application, with a higher level of entrepreneurial competence having been found to have a positive influence on farm performance, thus pointing to better repayment ability. The influence of entrepreneurial competency on performance therefore justifies the possible inclusion thereof in the credit application process, and this factor should be investigated further in future research studies.

The results show that there is consensus on the factors that are considered in determining the repayment ability of farmers. Such consensus is a good indication that there may be a high level of consistency in the classification of applications. However, further investigation revealed that the decisions in terms of classification are based on human judgement. The use of human judgement does have certain disadvantages, such as high training costs, as well as frequent incorrect and inconsistent decision-making by different experts on the same application. When the respondents were asked to indicate whether the use of objective credit-scoring models would assist in improving the consistency of the classifications, most indicated that the use of statistical methods could improve consistency in credit-granting decisions, but some limitations were also mentioned.

It is therefore recommended that further research be conducted to investigate the implementation of objective statistical methods to determine repayment ability within the South African agricultural sector where these identified factors can be implemented to extend or contribute to the current decision 
making variables in credit instruments. Research would include identifying measurement instruments to identify and/or measure these identifying factors in such a way that the factors can be included in the credit instruments. Such research would not only be to the advantage of the South African agricultural sector, but could also be successfully applied to other developed and developing countries.

Acknowledgments: This work is based on the research supported in part by the National Research Foundation of South Africa for the grant, Unique Grant No. 94132. Any opinion, finding, and conclusion or recommendation expressed in this material is that of the authors and the NRF does not accept any liability in this regard.

Author Contributions: Johannes I. F. Henning is a Ph.D. student and was the main researcher in the study who contributed in all aspects; including conceptualizing, designing, analyzing and interpreting the data; and writing the manuscript. Henry Jordaan, as supervisor and co-author, assisted throughout the research by contributing to the conceptualization and designing, editing, and critically reviewing the work.

Conflicts of Interest: The authors declare no conflict of interest.

\section{References}

1. Groenewald, J.A. Conditions for successful land reform in Africa. S. Afr. J. Econ. Manag. Sci. 2004, 7, 673-682.

2. Pretty, J. Agricultural sustainability: Concepts, principles and evidence. Philos. Trans. R. Soc. Lond. B: Biol. Sci. 2008, 363, 447-465. [CrossRef] [PubMed]

3. Kizilaslan, H.; Adiguzel, O. Factors affecting credit use in agricultural business concerns in Turkey. Res. J. Agric. Biol. Sci. 2007, 3, 409-417.

4. Hou, J. A Measurement of the Small Business Credit Gap and the Use of Credit Scoring by Small Financial Institutions. Ph.D. Thesis, University of Kentucky, Kentucky, UK, 2006.

5. Zellar, M.; Sharma, M. Rural Finance and Poverty Alleviation, No. 8; International Food Policy Research Institute (IFPRI): Washington, DC, USA, 1998.

6. Hananu, B.; Abdul-Hanan, A.; Zakaria, H. Factors influencing agricultural credit demand in northern Ghana. Afr. J. Agric. Res. 2015, 10, 645-652.

7. Chauke, P.; Motlhatlhana, M.; Pfumayaramba, T.; Anim, F. Factors influencing access to credit: A case study of smallholder farmers in the Capricorn district of South Africa. Afr. J. Agric. Res. 2013, 8, 582-585.

8. Ololade, R.; Olagunju, F. Determinants of access to credit among rural farmers in Oyo state, Nigeria. Glob. J. Sci. Front. Res. 2013, 13, 17-22.

9. Akudugu, M. Estimation of the determinants of credit demand by farmers and supply by rural banks in Ghana' s upper east region. Asian J. Agric. Rural Dev. 2012, 2, 189-200.

10. Dzadze, P.; Osei, M.J.; Aidoo, R.; Nurah, G.K. Factors determining access to formal credit in Ghana: A case study of smallholder farmers in the Abura-Asebu Kwamankese district of central region of Ghana. J. Dev. Agric. Econ. 2012, 4, 416-423.

11. Henning, J.I.F.; Jordaan, H. Investigating factors considered in agricultural credit applications, what are currently considered by a commercial bank? In I, Healthy Agriculture for a Healthy World, Proceedings the 20th International Farm Management Congress, Quebec City, QC, Canada, 12-17 July 2015; Watson, H., Lipari, M., Gendron, S., Bouchard, M.-C., Couture, S., Nadeau, N., Eds.

12. Delbecq, A.L.; van de Ven, A.H.; Gustafson, D.H. Group Techniques for Program Planning: A Guide to Nominal Group and Delphi Processes; Scott, Foresman \& Co.: Glenview, IL, USA, 1975.

13. Dalkey, N.C.; Helmer, O. An experimental application of the Delphi method to the use of experts. Manag. Sci. 1963, 9, 458-467. [CrossRef]

14. Hsu, C.-C.; Sandford, B.A. The Delphi technique: Making sense of consensus. Pract. Assess. Res. Eval. 2007, 12, 1-8.

15. Dalkey, N.C. An experimental study of group opinion. Futures 1969, 1, 408-426. [CrossRef]

16. Lindeman, C.A. Priorities within the Health Care System: A Delphi Survey; American Nurses' Association: Kansas City, MO, USA, 1981.

17. Linstone, H.A.; Turoff, M. Introduction. In The Delphi Method: Techniques and Applications; Linstone, H.A., Turoff, M., Eds.; Addison-Wesley Publishing Company: Reading, MA, USA, 1975; pp. 3-12.

18. Martino, J.P. Technological Forecasting for Decision-Making; McGraw-Hill, Inc.: North-Holland, The Nertherlands; New York, NY, USA, 1983. 
19. Young, S.J.; Jamieson, L.M. Delivery methodology of the delphi: A comparison of two approaches. J. Park Recreat. Adm. 2001, 19, 42-58.

20. Keeney, S.; Hasson, F.; McKenna, H.P. A critical review of the delphi technique as a research methodology for nursing. Int. J. Nurs. Stud. 2001, 38, 195-200. [CrossRef]

21. Dalkey, N.C. The Delphi method: An experimental study of group opinion. In Studies in the Quality of Life: Delphi and Decision-Making; Dalkey, N.C., Rourke, D.L., Lewis, R., Snyder, D., Eds.; Lexington Books: Lexington, MA, USA, 1972; pp. 13-54.

22. Douglas, D.C. A Comparative Study of the Effectiveness of Decision Making Processes Which Utilize the Delphi and Leaderless Group Methodologies. Ph.D. Thesis, The Ohio State University, Columbus, OH, USA, 1983.

23. Ludlow, J. Delphi inquiries and knowledge utilization. In The Delphi Method: Techniques and Applications; Linstone, H.A., Turoff, M., Eds.; Addison-Wesley Publishing Company: Reading, MA, USA, 1975; pp. 102-123.

24. Beech, B. Studying the future: A delphi survey of how multi-disciplinary clinical staff view the likely development of two community mental health centres over the course of the next two years. J. Adv. Nurs. 1997, 25, 331-338. [CrossRef] [PubMed]

25. Gibson, J.M. Using the Delphi technique to identify the content and context of nurses' continuing professional development needs. J. Clin. Nurs. 1998, 7, 451-459. [CrossRef] [PubMed]

26. Green, B.; Jones, M.; Hughes, D.; Williams, A. Applying the delphi technique in a study of gps' information requirements. Health Soc. Care Community 1999, 7, 198-205. [CrossRef] [PubMed]

27. Loughlin, K.G.; Moore, L.F. Using delphi to achieve congruent objectives and activities in a pediatrics department. Acad. Med. 1979, 54, 101-106. [CrossRef]

28. Seagle, E.D.; Iverson, M. Characteristics of the Turf Grass Industry in 2020: A Delphi Study with Implications for Agricultural Education Programs. Ph.D. Thesis, University of Georgia, Athens, GA, USA, 2001.

29. Putnam, J.W.; Spiegel, A.N.; Bruininks, R.H. Future directions in education and inclusion of students with disabilities: A delphi investigation. Except. Child. 1995, 61, 553.

30. Von der Gracht, H.A. Consensus measurement in delphi studies: Review and implications for future quality assurance. Technol. Forecast. Soc. Chang. 2012, 79, 1525-1536. [CrossRef]

31. Buck, A.J.; Gross, M.; Hakim, S.; Weinblatt, J. Using the delphi process to analyze social policy implementation: A post hoc case from vocational rehabilitation. Policy Sci. 1993, 26, 271-288. [CrossRef]

32. Zinn, J.; Zalokowski, A.; Hunter, L. Identifying indicators of laboratory management performance: A multiple constituency approach. Health Care Manag. Rev. 2001, 26, 40-53. [CrossRef]

33. English, J.M.; Kernan, G.L. The prediction of air travel and aircraft technology to the year 2000 using the delphi method. Transp. Res. 1976, 10, 1-8. [CrossRef]

34. Sekaran, U. Research Methods for Business: A Skill Building Approach, 4th ed.; John Wiley \& Sons: New York, NY, USA, 2003.

35. Grobbelaar, S.S. R\&D in the National System of Innovation: A System Dynamics Model. Ph.D. Thesis, University of Pretoria, Pretoria, South Africa, 2006.

36. Tauer, L.W.; Lordkipanidze, N. Farmer efficiency and technology use with age. Agric. Resour. Econ. Rev. 2000, 29, 24-31.

37. Phelan, C. Understanding the Farmer: An Analysis of the Entrepreneurial Competencies Required for Diversification to Farm Tourism. Ph.D. Thesis, University of Central Lancashire, Preston, UK, 2014.

38. Featherstone, A.M.; Wilson, C.A.; Kastens, T.L.; Jones, J.D. Factors affecting the agricultural loan decision-making process. Agric, Financ. Rev. 2007, 67, 13-33. [CrossRef]

39. Gustafson, C.R. Credit evaluation: Monitoring the financial health of agriculture. Am. J. Agric. Econ. 1989, 1145-1151. [CrossRef]

40. Wilson, C.A.; Featherstone, A.M.; Kastens, T.L.; Jones, J.D. Determining What's Really Important to lenders: Factors Affecting the Agricultural Loan Decision-Making Process. Available online: http://ageconsearch.umn.edu/bitstream/28678/1/sp060007.pdf (accessed on 20 April 2015).

41. Luthans, F.; Youssef, C.M.; Avolio, B.J. Psychological Capital; Oxford University Press: New York, NY, USA, 2007; p. 3.

42. Lambing, P.A.; Kuehl, C.R. Entrepreneurship, 3rd ed.; Pearson Education: Upper Saddle River, NJ, USA, 2003; p. 26. 
43. Baron, R.A.; Shane, S.A. Entrepreneurship: A Process Perspective; South-Western: Thomson, OH, USA, 2005; p. 292.

44. Bird, B. Towards a theory of entrepreneurial competency. Adv. Entrep. Firm Emergence Growth. 1995, $2,51-72$.

45. Baum, J.R.; Locke, E.A.; Smith, K.G. A multidimensional model of venture growth. Acad. Manag. J. 2001, 44, 292-303.

46. Colombo, M.G.; Grilli, L. Founders' human capital and the growth of new technology-based firms: A competence-based view. Res. Policy 2005, 34, 795-816. [CrossRef]

47. Lerner, M.; Almor, T. Relationships among strategic capabilities and the performance of women-owned small ventures. J. Small Bus. Manag. 2002, 40, 109-125. [CrossRef]

48. Chandler, G.N.; Jansen, E. The founder's self-assessed competence and venture performance. J. Bus. Ventur. 1992, 7, 223-236. [CrossRef]

49. Mitchelmore, S.; Rowley, J. Entrepreneurial competencies: A literature review and development agenda. Int. J. Entrep. Behav. Res. 2010, 16, 92-111. [CrossRef]

50. Man, T.W.; Lau, T.; Chan, K. The competitiveness of small and medium enterprises: A conceptualization with focus on entrepreneurial competencies. J. Bus. Ventur. 2002, 17, 123-142. [CrossRef]

51. Bolton, C. Logistic Regression and Its Applications in Credit Scoring. Master's Thesis, University of Pretoria, South Africa, 2009.

52. Marqués, A.I.; García, V.; Sánchez, J.S. A literature review on the application of evolutionary computing to credit scoring. J. Oper. Res. Soc. 2013, 64, 1384-1399. [CrossRef]

(C) 2016 by the authors; licensee MDPI, Basel, Switzerland. This article is an open access article distributed under the terms and conditions of the Creative Commons by Attribution (CC-BY) license (http:/ / creativecommons.org/licenses/by/4.0/). 